\title{
RELIGION AND THE WOMEN LEADERSHIP QUESTION (A PHILOSOPHICAL APPROACH)
}

\author{
Ikechukwu Nwakaeze - Ogugua (Ph.D) \\ Department of Philosophy, Nnamdi Azikiwe University, Awka \\ E-mail address: paiykeo@yahoo.co.uk
}

Keywords: Religion, women leadership question, philosophical approach

\begin{abstract}
Culture is a wider matrix than religion. The relation of male to female in Africa is cultural and metaphysical. The concept of womanhood is set as an appendix, hence derived from the concept of manhood, little surprising, how other structures socio-political are patterned that way reflecting the role of man making the world a masculine one. The society is a mystery of man.

I think what religion suggests is the putting in place of the structures necessary for realization of human potentialities and development of virtues such as love, justice, peace, prudence justice, etc. Religion did not deny that there may be areas of overlap as regards some qualities, characteristics or abilities in both sexes. Even as that it gave them vital roles such as judges, prophets but never headship both in the old and new testaments. Religion may advocate women taking part in political leadership of their nations but not as overseers, rather as helpers for they were called helpmate(s) in Genesis. God said it is not good that man will be alone, let me make him a helpmate meet for him.
\end{abstract}

\section{INTRODUCTION}

We are poised in this essay to examine the women leadership question from the religious perspective. Owing to the fact that there are many religions such as Christian, Islamic, Buddhism, African traditional religion, Eckankar, etc., and some of these do not qualify as religion if one goes about to define religion as belief in the transcendent or supreme Reality (God) but become incorporated if one uses the family resemblance definition, it becomes imperative to point out ' $h \mathrm{ic}$ et nunc' that we are concerned with the Christian religion. In order to set our sail on the right path, we need to be abreast with the issues involved in our topic, issues like religion, in this context Christian religion, and leadership. Concepts and issues remain the same but perception and interpretation of these differ, that makes the difference. Christian religion does not have one meaning, it has multi-faceted interpretation and as such many nuances of its meaning abound. Here lies the problem number one. Often, some people tend to tilt towards the conservative conception of Christian religion, few take to the extreme conception and many hold the moderate view of the Christian religion.

We can ask ourselves, is the issue of leadership important in its religious conceptualization? What of women leadership? The way women leadership is viewed and understood in the religious sphere may not be exactly the way it is perceived and understood in the social sphere. On account of the fact that our topic is enshrined within the religious matrix, we have to examine women leadership through the mirror of Christian religion.

In the bid to grapple with this essay, we have to examine the definitional problem which enshrouds our topic; examine the religious issues involved in women leadership question and see if there are contributions Christian religion could make in the advancement of women leadership issue.

\section{DEFINITION IMPERATIVE: PROBLEMATIC}

The problem associated with giving any definition which would be generally accepted with regard to religion is enormous; it is not lesser when one turns to specifics, i.e. Christian religion; likewise when one focus on leadership. It is difficult but not insolvable. In order to put our paper in proper focus and light, there is need to specify the different loci of these problems in the bid to 
perceive the issues involved and develop a fairly balanced conceptual framework and get at real conceptualization of our basic terminologies.

As the nuances in conceptualization of Christian religion differ, let us state in a nutshell briefly the major perceptions of this phenomenon. For the conservatives, Christianity has to do with bringing to the focus the spirit of the old and new testaments. The presence of Christ and his salvific role has nothing to do with the structure of biblical revelations. For them, the coming of Christ has not abrogated the laws; of course Christ himself said, he has not come to destroy the laws but to fulfill the laws and the prophets. The Sabbath, Cherubim and Seraphim, Celestial, Odozi Obodo, etc can be said to belong to this group.

For the liberals, anything can go under the canopy of Christianity provided the name JESUS is mentioned. Usually they maintain a-middle-of-the-road approach and prefer a Christianity that is practical, lively, that is one with a human face. This is behind the slogan 'a living church' - a church that does not have any order, not regimented, probably without a creed or dogma. This gives their leaders a field day, changing from one thing to another under the guise of operating in the Holy Spirit. According to Ozumba (2002:108),

They may permit the total depravity of man and man's irredeemability. They excuse sin on the basis of human weakness, foibles, failings and short-comings.

Some of them are disciples of Martin Luther.

The moderate sect within this group may preach and argue that the important thing is the grace of God, hence one need to appropriate it. Again, that this grace of God covers sins and does not wipe away sins. If left on their own, they would remove the entire Decalogue or the most difficult ones to allow man to enjoy himself. They at times are very critical with regard to the place of Old Testament theology in this New Testament dispensation. For some of them, since they give room for everything, the Holy Spirit having graduated in knowledge can order the ordination of women priests, etc. The Pentecostal churches most of which run on the frenzy emotions of the people mostly women are notable.

The extremists conceive Christianity in the strict sense. They are the religiously religious people, who are more Christian than Christ himself. They are fastidious about the letters of the law more than the spirit of the law. In short, they are the zealots and fanatics.

For these people, every Christian should observe all the laws in the old and new testaments. They hold to the point that every Old Testament law should be applied today save those ones that are already fulfilled in the person of Jesus Christ. Ozumba (1002:109) maintains that:

The extremists maintain that, following strictly the teachings of Christ, we can ascertain the measure of the interplay between grace and works, humanity and divinity, all at work in a synthetic complementarity to lead man to the ultimate which is eternal salvation.

People in this group are the puritans and pietists; who are usually prudery.

As configurations abound in Jesus' time, they still abound today in plenty. One might think of the deeper life, Christ Embassy, Grace of God, and such like Brotherhood of the Cross and Star (OOO).

Christianity does not end in profession, it is practical thing, a way of life hence it is realistic and not hypocritical.

Within Christendom, we have multiple groups each claiming it is the be it and end it all when it comes to understanding and interpreting the scriptures under the guidance of the Holy Spirit. The problem lies in knowing how the Holy Spirit can be at the foundation of conflicting interpretations of the same passage. Such groups include the Orthodox i.e. Catholic Church and Anglican Church, Evangelicals i.e. the Pentecostals and the prosperity groups. At times; it is difficult to point out the difference between the Pentecostals and the prosperity groups. For the 
former, the Winner can represent, likewise Grace of God Mission; and for the letter Zoe Ministries of Awuzie does represent, even the Ministry of Chris Oyakhilome, Christ Embassy does represent too. The question raising its head at this point of our discourse is, how do we determine this issue of women leadership from this point of view? Don't you see there will be a cacophony of voices, at times stressing some common beliefs and at other times emphasizing different issues? In short, the approach though it may seem complementary is rationally discriminatory all the more.

If we leave this trend as such, it will be difficult to achieve anything worth it. There is need to harmonize the positions and emphasis of these groupings at least conceptually or else there will be no emerging focus to serve as the basis for our discourse. There is no doubt the extremists will hold unto the letters of the Holy Writ, without giving any regard to the existential situation and even over spiritualize the fact that the woman must be under a man even an idiot of a man, and even make it an article of faith. The liberals will no doubt given enough room for change, as they will argue without mincing words that the society is dynamic and man must change inorder to fit into the times. Moreso, that God desires our happiness, hence if women should rule better it will be given to them. The conservatives will tilt more towards the extremists, or at best try to maintain a balance between the letters of the Holy Writ and the spirit of the Holy Writ (between the spiritual and the human).

It does stand to reason that the conservatives and the liberals because they think about the mundane, the temporal such as human goodness, e.t.c. enjoying the bounties of God in the concrete inorder to be really human. The extremists think more of the divine and heaven lies as such he sees the eternal gains as more important such that even if men misrule, it will only be for a time, just temporal. Women need not bother themselves with leadership, inorder to be in a position to ear heaven and avoid the snags and dirtiness associated with leadership.

Out of all these groupings, the liberals are most likely to argue for the putting in place of structures and formulation of policies which will enhance the participation of women in leadership of nations for the women have equal rights with men among these include: the right to life, to freedom of speech, to be voted for and to vote. The extremists, will not see the denial of women the rights to be voted for as new, rather it is one of the game plans for making heaven as the earth is for training, more so, the earth is not a perfect city.

It is the concern of this paper to see if there is any way the Christian religion could improve the chances of women interested in and gifted with the gift of leadership to aspire to govern into their respective nations. That will entail exploring the doctrinal, eschatological, attitudinal and visionary dimensions of Christian religion. There is no doubt that religion has a rule in the explication, interpretation, understanding, conceptualization, application and administration of issues concerned with leadership. Does it have such bearing on women leadership?

Leadership gains its cogency, nationality, validity because power lies with the people and to the fact that every leadership comes from God whether oppressive or not. The scriptures say all things work well for the people of God. It is in this vein, that the discourse Christian religion and women leadership becomes very crucial at this time that feminism is making many women run crazy even to the point of forgoing their basic and primary responsibilities in search for non-existent and ill-conceived equality of sexes.

Women leadership discourse has gathered weight, and is controversial; it has the propensity of affecting every sphere of our society, as such it need not be wished away, rather it need be settled if our society will be properly harmonized and integrated for fruitful progress. Unsettled human rights questions landed the world in the pit of terrorism, who knows where unsettled women leadership questions will land the nations? Probably, in broken homes or conflict of the sexes. That is why, we want in this paper to resolve this issue as far as human reason can go. Inorder to fully participate in this piece of discourse, we have to define our operative concepts. 


\section{DEFINTION IMPERATIVE: CONCEPTS}

Some concepts stand out in our paper i.e. religion, politics and leadership. In 'strictu sensu' two terms stand out namely Christian religion and women political leadership. Question like what is religion? What do we mean by Christian religion? Leadership, women political leadership, etc? Can be raised as well. Ogugua (2004:2) writes that

Religion is a striking phenomenon in human life. Nobody can sincerely evade or ignore it. There is no other force or phenomenon which moulds the life of man in the society as religion does.

What then is religion? The term religion comes from the Latin 'religando', 'religendo', and 'reelegere'. 'Religando' means binding back, it suggests God binding man back after the fall of man. 'Religando' means to re-read; possibly continuous reflection and meditation on the Divine. 'Reelegere' means re-election, connoting the idea of continuous experience. Although there are nuances of meanings, religion still difficult to define, does not portend it is an elusive concept. Ogugua (1999:1) rightly pointed it out thus: "Religion like most concepts is not very easy to define... This concept is slippery, hence it constantly changes faces and shifts ground".

Religion has analogical character for no one definition says all one wants to say about it. Bouquet, A.C. (1941:16) sees religion as: "A fixed relation between the human self and some non-human entity, the sacred, the supernatural, the self-existent, the absolute or simply, God". Omoregbe (2000:3) agreed to this; he holds it is "a relationship established between man and a transcendent personal being, a deity, believed to exist". Ogugua (2004:11) stressed poignantly that

Religion does not consist in mere acceptance of a reality determined as sacred, even less in a purely subjected state of consciousness. It is simply put, a complex phenomenon having dialectical relationships of the mind to reality. It is dialectical because it is both active and passive, but more because it continues to negate its acquired position. In this process it opens up a new dimension in human existence.

That shows religion is not an 'apriori' definable reality. The problem we have with the definitions of religion above is that they drew the curtain over some 'religions' like Buddhism, Hinduism, etc. Religion is both a complex phenomenon, and an individual cum group thing.

To understand religion, the three great realities involved need be considered; they are God, the world and man. 'Genus ad differentiam' definitions will not solve our problem rather family resemblance definition will help us. That means anything, which has a set of characteristics or some of these qualities could be called a religion. Alston posited these characteristics:

1. Belief in Supernatural Being.

2. Distinction between the scared and the profane

3. A moral code believed to come from God (or gods)

4. Rites

5. Sense of give and mystery.

6. Prayer or any other forms of communing with God or (gods)

7. A world-view.

It is by this way of extending the concept of religion these other religions fall into the term religion.

The Christian religion is not less difficult to define. The concepts 'Christian' and 'religion' are multivoeal and like other slippery term is not easy to be captured by a single or a uniform definition. It is difficult to force all the appearances or shades of meanings into a definitional cast or mould. It does seem going the phenomenological and existential paths will lessen the task and give us a focus, as we then dwell on getting at the essence and the results of the Christian religion.

Christ and his teachings are central to Christian religion. We can say that it is grounded on the Old Testament theology, the Torah, Kabalah, etc., and the person of Jesus Christ for he said he has come to fulfill the laws and the prophets. Ozumba (2002:113) argues that Christ: 
only abrogated the aspect of the old Testament which He Himself has fulfilled especially in the ceremonial observances. Jesus is the culmination, fulfillment, perfection, and the antitype of all that the Old Testament tried to present merely in a figure. It is therefore in Christ's life, ministry, teaching, death, resurrection has its bulwark.

By Christian religion, one might mean the charter of beliefs, doctrines, conducts, practices and worship according to the mind and teachings of Christ. In a nutshell, it entails thinking as Christ thought, believing what Christ believed and living as he lived. With regard to women political leadership, it would entail handling it the way Christ handled it if he did and / or the very way he would have handled it if it were presented to him. We can ask, what would have been his injunctions and prescriptions on women leadership question? It suggests an examination of how Jesus would have reacted to the feminist demand and actions in this matter. This could be gotten through the biblical and extra-biblical (traditional) sources.

Another term of importance is women political leadership. What do we mean by leadership? What do we mean by political leadership and then women political leadership? This concept women political leadership is genderized and feminized. On account of this, it has invited into the discourse the concept of human rights such as the freedom of association, freedom to vote and be voted for, freedom to self-rule, etc. grounded on the value and dignity of the human life and person. By human rights, in this concept one does not mean the inalienable rights, the existential necessities needed for human preservation but human rights as a broader concept. For this broadened view of human rights to really accommodate this genderization of leadership, there is need for congenital freedoms, abilities and activities which will then become the yardstick for involvement in the onerous, all important game of leadership. For Plato, the greatest problem of political philosophy is who will rule? The question raising its head is this; will feminization of political leadership lead to much more freedom and justice in the State? As justice is the chief virtue of the State, if it will lead to justice, are there qualities women possess that will lead to this which men do not possess? Are women just and men unjust? There are some just people in both sexes. Men are said to be more rational and women more emotional, does emotive attachment lead to justice?

Women have tactfully and dutifully moved from one request to the other with the vigour and strength of a tiger. They asked for: destruction of traditional practices militating against their development, removal of obstacles to their economic empowerment participation in the governance of their states; today they are asking for equality of the sexes. Logic has told me that equalization of the sexes cannot solve the problem were it possible. Experience and nature join forces to defeat it. The only possible and realizable option is equity; though not very easy to delineate and operate.

Women political leadership should mean 'allowing' women to participate in the political leadership of the states. The question is, who is making the case for the men? Nobody, save men themselves. Whenever women are ready to participate they should make their own case. Nobody has ever legislated that women should not participate in political governance of their States.

\section{HANDLING THE ISSUES}

Is there any Christian conception of women political leadership? The Bible lets us know that political leadership comes from God. The stories of the people of Israel, and God's provision of leaders to lead them portend that much.

Most contemporary societies are male-dominated and directed. Likewise the past societies. The world has been and is regarded as a male-one. Enemuo, F. (1999:228) writes: these societies "in varying degree,... harbour beliefs, moves and practices which objectively permit or promote the economic exploitation of women and their political marginalisation". Our emphasis lies in political marginalisation. How do we trace its genesis and see how and when Christianity started talking about it. The right to rule is politically enshrined in the right to vote and be voted for which is subsumed in the concept of human rights. 
In the ancient times, rights were not seen as inalienable, rather they are functional for actualization of roles. In Jewish culture, Athenian, Greek culture and even in African traditional culture, the distinction between male and female species was clear. Women were almost regarded as chattels, hence had no rights. Even within the male species, the freedom and the slave are not placed on the same pedestal. They had rights while the latter had none. Rights talked about then was prejudicial, highly discriminatory or else why did Aristotle hold that "it is meet that Hellenes should rule over barbarians" cited by Iwe (1994:30). Ancient Rome was characterized by anti-human right forces inspite of her level of civilization.

There is no gainsaying in holding that the customary practices of many traditional and even contemporary societies are biased against women, thereby subjugating them under men and in this way undermined their self-esteem. This no doubt, entrenched a feeling of inferiority in women placing them at disadvantage when compared to men.

Enthronement of human rights is grounded on Christian conception of man as made in the image of God. Has the same Christian Conception of man the possibility of doing the same for women political leadership issue? Let us search (and rummage) the scriptures. God in Genesis (3:16) made it clear that man should rule over the woman. He said, "...yet your desire shall be for your husband, and he shall rule over you". St Paul in his Epistle to the Corinthians (11:3 \&7) said the head of every man is Christ, the head of the woman is her husband; and that man is the image and glory of God; but the woman is the glory of man. This man of God, Paul, in his letter to the Ephesians (5:22-24) admonished:

Wives, be subject to your husbands, as to the Lord. For the husband is the head of the wife as Christ is the head of the Church, his body, and is himself its saviour. As the Church is subject to Christ, so let wives also be subject in everything to their husbands.

There is no sphere of life, that men are said to have headship, but in every aspect. The disciple Timothy even went an extra mile and said in (1 Timothy 2:12): "I permit no women to teach or to have authority over men; she is to keep silent."

Inspite of Jesus' injunction that we shall love the other and his deep concern for women and love for them, he did not choose any lady or woman as any of his apostles. Jesus had his reasons. He did not make his mother the leader of the apostles, rather he chose Peter.

Even in this contemporary period, orthodox religious sects have despite the pressure mounted by feminists and pro-feminists refused to ordain women as priests or prelate in obedience to the example of Jesus. Christian religion is based on love and other related virtues such as: justice, peace, faith, humility, equality ( 1 think not equality of sexes but that of opportunities) etc, it is not based on political leadership. In the atmosphere of love and peace there will be no point struggling over who rules for there will be requisite freedoms and existential conditions for proper human development. This will take us to the philosophical sphere and problems as regards the topic.

\section{PHILOSOPHICAL PROBLEMS INVOLVED IN WOMEN POLITICAL LEADERSHIP}

The issue of human rights has a divine root, but does the question of women political leadership have this divine sanction? Although it took flesh from the idea of political freedom, it does not have this divine root. Love of God and fear of God the Bible says are the beginning of wisdom, these too are the twin pillars for creating enabling environment for upholding of the human rights.

There is a litany of unanswered as well as unasked questions in the topic. We ask are there in-built checks and balances to harmonize the limits of our freedoms as individuals and as members of different sexes? Where does a husband's (man's) freedom end and that of a wife (women) begins? Philosophers and thinkers all agree that man is a free and rational animal. Jean Paul Sartre for instance argued that man is condemned to freedom, as such he is responsible for his acts. Jean Jacques Rousseau holds that "man is free but everywhere in chains." Of course, women are 
involved, so the question is how do we liberate man from the chains fettering his actualization of his nature in every sphere of life?

The universal moral law holds in its first principle that good is to be done and evil avoided. The second principle is on self-preservation, on account of these there is need for man to be conscious of respect for oneself and that of the other. What is good for the goose is good for the gander. The universal dictum of doing unto others as you would expect done unto you points towards this.

If human nature is the same, reason will tell us to accord the same treatment to members of the human species. Jean Grimshaw (1997:54) stated:

Theories of human nature have had a central importance in philosophy. Their importance arises out of the frequent concern, in moral and political philosophy, to try and spell out a conception of a form of life for human beings, a mode of political and social arrangements, an ideal of human development, which is both possible and desirable.

Is human nature the same? Does human nature set a limit on the sort of social and political arrangements possible and realizable? At times, we hear people say it is human nature or it is only human. Does it mean that human behaviour is unalterable and unchangeable? There is no theory of human nature which holds absolute fixity of human behaviour. Certain things can be against nature, unnatural, that does not mean there are possible and/ or desirable. For instance, the position of socio-biological theory is clear and Grimshaw (1997:55) argues from it thus:

It might be argued that while some women may want and seek equality with men in the short term, in the long run the need of women to care for their offspring under male protection is a more "fundamental" aspect of female nature and will defeat efforts to seek equality.

Again there might arises conflicts between group's desires, and those conflicts are better resolved in ways compatible with human nature or else man reaps doom. Theories of human nature tend to point being truly human. The characteristics of real humanity will aid in assessing social arrangements and conceptualization of untapped, unrealized human potentialities, and seek ways to realize these possibilities.

The question that raises its head, now, is does human nature specify social roles for both sexes? Or determine certain sorts of social controls? Hobbes for instance, wished and thought away social control and landed in his state of nature, which would be 'nasty, brutish and short:

There is a claim that there are natural physiological cum psychological differences between the sexes. Opinions vary, some argue that some roles should be sex roles, they base their view on the natural differences between the sexes, others argue that since there is no difference in innate psychological traits or even if there is that it is not evident, there is no need for sex roles. For Trebilcot, whether there are psychological differences or not it has very little bearing on the issues of whether the society should reserve roles for the sexes.

It is the biological differences that segmented human beings into male and female. Apart from this difference, there are natural difference, there are natural differences in temperament, abilities, interest, etc. Arguments about the non-existence of physiological difference will be madness for it is self-evident. Let us rather look at the arguments springing up from psychological differences as the ground for sex roles. The Hormone secreted by the testes makes the male brain different in structure and probably operation than the female brain as depicted by Money John et al (1972). There is a psychoanalytical viewpoint which holds that female or male behaviour respond to this bodily structure. Is this not why Freud explained personality sexually. So female's behaviour is based on their being penis envious, and their castration complex. (This might suggest why women do not see themselves as fulfilled till they have a male child). Joyce Terbilcot attests:

Other writers make much of the analogies between genitals and genders: the uterus is passive and receptive, and so are females; penises are active and penetrating, and so are males. 
The fact is that the actual distribution of traits between the sexes is lacking. We can then ask is it possible to assign sex roles? If it is possible, is it good? If it is good, is it desirable? Or should the society then enforce sex roles? What of the members of the sexes who are outside the sexually constructed mould, those who perform the other sex's roles better (of course outside the reproductive role), those who are abnormal?

Some have argued for societal institutionalization of sex roles based on the three reasons we are going to discuss below. Firstly, that on account of the psychological differences between the sexes, sex roles are inevitable. According to Terbilcot,

The argument assumes first that the alleged natural differences between the sexes are inevitable; but if such differences are inevitable, differences in behaviour are inevitable, society will inevitably be structured so as to enforce role difference according to sex.

Even if there are psychological differences between the sexes, it does not follow that sex roles are inevitable. Although the society can assign roles to sexes if it is discovered that there is a correlation between them. That does not make it inevitable. Even if the correlation is inevitable, institutionalization of sex roles need not be enforced, for a certain role may not be inevitable for some members of a particular sex irrespective of the fact that their sex perform the role in question very well. Mill (1959) poignantly pointed out:

The anxiety of mankind to interfere on behalf of nature, for fear lest nature should not succeed in effecting its purpose, is an altogether unnecessary solicitude.

Does that expression of Mill suggest giving room for individual differences? There is need to value and appreciate the value and worth of human life, and allow man to act out his freedom, such that those individuals who vary from the statistical norm should not be coaxed to conform to it.

Secondly, the argument from well being: it holds that members of the sexes are happier in certain roles than others. It stands to reason backed by experience that some members of a sex will choose contrary to their own well- being. For instance, smoking causes cancer, and still even medical doctors are 'chain smokers'. There are areas of life where these sexes overlap. Having seen this, institutionalization of sex roles will only make sense if it is proved that the loss of potential happiness in adhering to specific sex roles is less than that which will result if individuals are allowed to choose freely what roles to perform. Even if greater happiness is realizable by a sex's performance of a particular set of roles, it does not follow that there should be sex roles.

Thirdly, the argument based on efficiency. If the differences between the sexes make for different abilities in performance of certain roles, then it is reasonable to assign such roles to the sex that will perform better due to the innate ability it possesses. Efficiency alone cannot determine if sex roles should be (societally) socially enforced, other reasons need be examined and weighed. Efficiency is determined by looking at the level of proficiency. This argument provides a weak reason with slender feet to opt for institutionalization of sex roles. Joyce Trebilcot states: "it is frequently pointed out that the argument from nature functions as a cover, as a myth to make patriarchy palatable to both women and men". Male and female share in human nature; what is important is not what each sex is naturally but how can these sexes live in a society and realize their humanity. The question is, what kind of society is morally justifiable and capable for realization of human happiness and development? To give adequate responses to these questions, some moral concepts like freedom, justice, love, equality, etc need be looked at.

Feminists have argued that the female nature tied to specific social roles have been instrumental to subjugation and exploitation of women. Probably too their economic stagnation, political marginalisation and thwarting of their personalities. Theories about the female nature have been used to legitimate some practices in the society and postulation of some policies. Feminists only share in their woes, they do not seem to share in the strategies and proposals to be adopted to realize the goals they seek. 
Theories of human nature have ideals of human potentiality, excellence, etc as masculine; suggest that constrains on male and female sexes are different. Grimshaw (1997:59) states:

These constraints account both for differences in the social roles and psychological characteristics of men and women, and for quite general features of human social relationships.

If we go to nature, biology, the feminist argument will flounder. Can we rightly hold that biology does not determine anything about human life? That will be an overstatement for nature does not make anything in vain.

The philosophy of political liberalism is dualistic. At times it is metaphysical, in a sense of the human mind being only continently connected to the human body. In the understanding of Jaggar Alison, where it is not metaphysical it is then normative. He states:

Normative dualism is the belief that what is especially valuable about human beings is a particular "mental" capacity, the capacity for rationality...Contemporary liberal theories ascribe political rights on the basis of what they take to be the specially human capacity for rationality, and disregard what they conceive as "merely physical" capacities and incapacities.

Scholars like Mill, Mary Wollstonecraft, etc argue that if given the opportunity to develop that women have the ability to develop. When they flower to the use of reason genderized characteristics will be played down or disappear. Then according to the liberals as expressed by Grimshaw (1997:61)

Sex would be a biological "accident" which while it would continue to have certain inevitable social consequences, would be irrelevant to the full development of human nature.

Women though victimized and brutalized by the force of male ideology can forge ahead. According to Andrea Dworkin, the humanity of women has been destroyed. Pornography even plays a part too. She states:

Woman is not born, she is made. In the making her humanity is destroyed. She becomes a symbol of this, symbol of that, mother of the earth, slut of the universe; but she never becomes herself because it is forbidden for her to do so.

Patriarchal forces have raped the minds of women and not only their bodies. The operation is mental. For Andrierine Rich, for women to

Live a fully human life we require not only control of our bodies (though control is a prerequisite); we must touch the unity and resonance of our physicality, our bond with the natural order, the corporeal ground of our intelligence.

At this point let us face our topic directly. We have seen that female nature is imbued with potentialities. Before the move for political leadership women liberation movement has made exploits in overthrowing some traditional practices, which held them hostage and raped their freedom. Their direction today is no longer human (women) empowerment, but gender equality and de-masculinization of political leadership as if there is a ploy to make it that. Some critical and necessary questions need be asked at this point, do women know that nature has its course of operation? Is it possible to change nature? Is it possible to humanize nature? If there is the possibility, is there any need to do it? if we can do it, is it desirable? Is gender equality possible? Must gender be equalized for women to become political leaders in different nations? Is gender equality legitimate in all cultures in the world? Does experience not teach and point to the fact that equality is not possible? Is the Bible not clear on the impossibility of equality? What is the theory of Darwin, survival of the fittest, has it not shown that inequality is the badge of the world? In the natural bodies too, it is difficult to maintain balance always or else why do we experience eclipse of the sun? The gender question is not even properly conceived; as it criss-crosses into different spheres of life, it is a fusion of cultural, historical and moral factors. 
Women have at no point in time being depowered politically by men. The equality they seek can only be realized within the moral sphere. Dukor, M. (1998:85) states: "it remains safer to think about equality of moral freedom than the equality in economic, material and intellectual lives of women and men". None of these spheres of equality is not replete with controversy. Equality in other spheres save moral is scientific and measurable to an extent that there are laws put in place to act as yardstick for assessment. It does seem according to Dukor (1998:87) that,

There is a difficulty in trying to reconcile the equality of men and women with a reasonable modicum of a corresponding freedom of man. Freedom comes into this discussion as an analytical correlate because for every form of equality, there is a corresponding freedom.

Each individual need to determine his place in the society at every point in time. Any attempt to equalize man and woman would be arbitrary encroachment on the just society weaved by natural cum cultural factors. Let us see what some philosophers think about this.

Plato, a renowned philosopher, posited an argument on gender equality, which is highly debatable if not inconsistent and self-contradictory. For John Locke,

There (is) nothing more evident than that creatures of the same species and rank promiscuously born to all the same advantages of nature, and the use of the same faculties, should also be equal to one amongst another, without subordination or subjection.

Here he argues for gender equality. But he was careful and quickly added "unless the Lord and Master of them all should be any manifest declaration of his will, set one above another..."

Of course, it was set out clearly in Genesis 3:16, Eph 5:22-24, 1 Cor. 11:3, etc that men should rule the women, and that women as glory of the man should obey the man. The Holy Writ did not limit the areas that the man should rule. By implication, the political sphere is (there) inclusive. In the same text, in book II, chapter VII paragraph 82, Locke acknowledged that man is the abler and stronger hence is naturally and necessarily the head of the family. Locke was more straight forward than Plato. In his Republic he stated:

A man and a woman have the same nature if both have a talent for medicine; whereas two men have different natures if one is a born physician, the other a born carpenter.

Although this is confusing, Plato replied yes to questions if there is great difference in nature between the sexes, and if the difference imply that both do different jobs.

Performance of duties with proficiency leads to efficiency. To perform one needs education, training, abilities, skills and interest. Every art is not the same, some require greater experience, ability, skill and years of tutelage than other. Talents required for engineering and that required for medicine may not be the same although both are sciences. Talents, skills, education and ability needed for medicine may not fit for political leadership. A man can be educated and yet a poor governor. Therefore, the fact that some women are educated and learned does not mean that they can govern very well. This is basically due to the fact that science and technology can be reduced to laws and sets of formulae, which one can master and apply. Politics is basically about human relationships, human beings and the society are dynamic, hence changes from time to time; hence it requires a delicate and calculated combination of knowledge, tact, courage, strength of character, experience, prudence, etc. It is commonplace to see some people who graduated from university and could not perform yet they have the requisite (and technical) know-how prescribed for the job.

Aristotle pointed out that the difference in the sexes, natural and psychological cannot be for fun. He maintained that

Temperance- and similarly fortitude and justice- are not, as Socrates held, the same in a woman as they are in a man. Fortitude in the one, for example, is shown in 
connection with ruling; in the other, it is shown in connection with serving; and the same is true of the other forms of goodness.

Goodness and excellence of the good man cannot be the same in a ruler and in a subject; so it must be of sorts. Aristotle said, a man would be said to be a coward if his courage only measures to that of a courageous woman. According to Aristotle these differences between man and woman are not by accident (rather they are natural in the sense of being endemic and universal; and not necessarily as a result of specific forms of human interaction, socialization and social relationships), for nature made man fitter to command than the female, except when there is some departure from nature as in the case of Joan d'Arc, Queen Amina of Kano, etc.

Where women rule or influence leaders greatly, we will have extreme democracy, luxurious life might abound, and all sorts of license granted, this will lead to fall of the civilization or nation. Aristotle pointed Sparta as an example; it fell due to "the mischievous influence of women".

Having come this far, we can see that the biblical support for women political leadership even through extensive logical inferences is weak, more so gender equality. The philosophical basis of gender equality is slender and weak, that for women political leadership is capable of being developed political leadership is capable of being developed all the more based on female potentialities and existential and historical events.

\section{CONCLUSION}

Culture is a wider matrix than religion. The relation of male to female in Africa is cultural and metaphysical. The concept of womanhood is set as an appendix, hence derived from the concept of manhood, little surprising, how other structures socio-political are patterned that way reflecting the role of man making the world a masculine one. The society is a mystery of man.

The Jewish culture equally mystified man, it is not uncommon that their religion Judaism reflected this understanding and Christianity toed the same line. In the scripture, you see that women are not counted. For example, Jesus fed 5,000 people outside women and children.

I think what religion suggests is the putting in place of the structures necessary for realization of human potentialities and development of virtues such as love, justice, peace, prudence justice, etc. Religion did not deny that there may be areas of overlap as regards some qualities, characteristics or abilities in both sexes. Even as that it gave them vital roles such as judges, prophets but never headship both in the old and new testaments. Religion may advocate women taking part in political leadership of their nations but not as overseers, rather as helpers for they were called helpmate(s) in Genesis. God said it is not good that man will be alone, let me make him a helpmate meet for him.

\section{References}

[1] Andrea Dworkin cited in Grimshaw (1986) Philosophy and Feminist Thinking U.S.A. Minnesota Press.

[2] Andrienne Rich (1997) "Who am I?" in Eliot Deutsch (ed) Introduction to World Philosophies . N.Y: Prentice Hall.

[3] Alston Cited in Ogugua, Paul (1999) Lectures on Philosophy of Religion (Unpublished) Department of Philosophy, Nnamdi Azikiwe University, Awka.

[4] Aristotle Politics trans by Sir Ernest, B., Book I, Chap XIII, Paragraph 9.p. 444.

[5] Book 1, Chap XII, paragraph 1, p. 40, see p. 5

[6] Book II, Chap IX, paragraph 6-10, p. 91-92

[7] Bouquet, A.C. (1941) Comparative Religion Middlesex: Penguin Books.

[8] Dukor, M. (1998) "How Not to Empower Women" in Dukor (ed) Philosophy and PoliticsDiscourse on Values and Power in Africa. Lagos: Obaroh and Ogbinaka Pub. Ltd. 
[9] Enemuo, F. (1999) "Gender and Women Empowerment" in Anifowose, R. and Enemuo, F. (eds) Elements of Politics Ibadan: Malthouse Press Ltd.

[10] Grimshaw, J. (1997) "Who am I?" in Eliot Deutsch (ed) Introduction to World Philosophies.NY: Prentice Hall.

[11] Iwe, N.S.S. (1994) The History and Contents of Human Rights Calabar: Seasprint Nig. Co. Ltd.

[12] Mill, J.S. (1959) "Some Psychological Consequences of the Anatomical Distinction between the Sexes" in James Starchy (ed) Sigmund Freud: Collected Papers N.Y: Basic Books.

[13] Locke, J. Two Treatise of Civil Government, Bk II, Chap. II, paragraph 4. Book II, chap. VII, paragraph 82.

[14] Ogugua, P.I. (1999) Lectures on Philosophy of Religion (Unpublished) Dept. of Philosophy Unizik, Awka.

[15] Ogugua, P.I. Religion: A Philosophical Insight Vol. 1 Nig: Double Pee Communications.

[16] Omoregbe, J. (2000) A Philosophical Look at Religion Lagos: Joja Educational Research and Pub. Ltd.

[17] Ozumba, G. (2002) "Christian Religion and the Human Rights Question" in Chris Nwamuo (ed) Calabar Journal of Liberal Studies, Vol. V, No. 1, July Calabar: Optimist Press.

[18] Plato Republic trans by Conford, F.C. Chap. XV, p. 148.

[19] Trebilcot, Joyce, "Sex Roles: The Argument from Nature: in Daniel Kolak and Raymond Martin (eds) The Experience of Philosophy California: Wadsworth publishing Co. 